\title{
Cytotoxic Activity and Molecular Docking of Indole Alkaloid Voacangine, Bis-indole Alkaloids Vobtusine, and Vobtusine Lactone from the Indonesian Plant: Voacanga foetida (Blume) Rolfe
}

\author{
Adriani Susanty ${ }^{*}$, Dachriyanus ${ }^{2}$, Yanwirasti ${ }^{3}$, Fatma Sri Wahyuni' ${ }^{2}$, Puteri Amelia ${ }^{4,5}$, Frengki ${ }^{6}$, \\ Ihsan Ikhtiarudin ${ }^{1}$, Yusuke Hirasawa ${ }^{4}$, Toshio Kaneda ${ }^{4}$, and Hiroshi Morita ${ }^{4}$ \\ 1. Sekolah Tinggi Ilmu Farmasi Riau, 28293, Pekanbaru, Riau, Indonesia \\ 2. Faculty of Pharmacy, Andalas University, Kampus Limau Manis, 25163, Padang, West Sumatera, \\ Indonesia \\ 3. Biomedical Science, Faculty of Medicine, Andalas University, 25127, Padang, West Sumatera, Indonesia \\ 4. Faculty of Pharmaceutical Sciences, Hoshi University, Ebara 2-4-41 Shinagawa-Ku, Tokyo 142-8501, \\ Japan \\ 5. Department of Pharmacy, Faculty of Health Sciences, Universitas Islam Negeri Syarif Hidayatullah, \\ Jakarta, 15412, Indonesia \\ 6. Faculty of Veterinary Medicine, Syiah Kuala University, Banda Aceh, 23111, Indonesia
}

\begin{abstract}
Info Article
Submitted: $13-04-2021$

Revised: $11-11-2021$

Accepted: $16-12-2021$

${ }^{*}$ Corresponding author Adriani Susanty

Email:

adrianisusanty@stifar-

riau.ac.id

ABSTRACT

The purpose of this study was to evaluate the in vitro cytotoxic activity of two isolated compounds from Voacanga foetida (Blume) Rolfe against the A549 cell line. The in silico study was carried out to predict the cytotoxic mechanism of two isolated compounds (vocangine and vobtusine lactone) and previously reported compound (vobtusine) against pro-survival receptors (Bcl-2, Bcl-xL, Mcl-1), pro-activation receptor (Bax), and apoptotic execution receptor (caspase-3). This research is an experimental quantitative using column chromatography and HPLC methods in the isolation process, MTT assay in determining the cytotoxic activity, and molecular docking in determining the prediction of ligand-receptor interactions. The fractions (VFB-DA, VFB-DB, VFB-BuOH, VFB-DB4) and voacangine exhibited very strong cytotoxic activity, while vobtusine lactone showed moderate cytotoxic activity. The docking scores for voacangine, vobtusine, and vobtusine lactone against Bcl-2 were -9.93; -10.07; -9.03 kcal/mol, against Bcl-xL were -9.77; $11.69 ;-9.76 \mathrm{kcal} / \mathrm{mol}$, against $\mathrm{Mcl}-1$ were $-10.70 ;-10.77 ;-9.53 \mathrm{kcal} / \mathrm{mol}$, and for Bax were $-8.99 ;-6.87 ;-6.99 \mathrm{kcal} / \mathrm{mol}$, as well as against caspase-3 were$12.05 ;-12.21 ;-12.02 \mathrm{kcal} / \mathrm{mol}$. The cytotoxic activity of voacangine, vobtusine, and vobtusine lactone was thought to cause cell death by suppressing Bcl-xL and Mcl-1 activities and also increasing Bax and caspase3 activities.
\end{abstract}

Key words: Voacanga foetida, vobtusine lactone, in vitro, in silico

\section{INTRODUCTION}

Cancer has an increasing incidence of morbidity and mortality. Current treatments include surgery, chemotherapy, radiation. All of which are aimed at killing cancer cells. However, the results are not satisfactory as side effects are alarming to sufferers. In the light of this, this study is to explore medicinal plants that are thought to kill cancer cells either by necrosis or apoptosis (Susanty et al., 2020).

At the cellular level, cancer can occur if there is a failure to respond to normal apoptosis, failure of proliferation inhibition, and loss of heterozygosity (LOH) (Kyzas et al., 2004). The part of the chromosome that contains the tumor suppressor gene is $\mathrm{LOH}$. The mechanism of cancer cell death can occur through two processes, necrosis and apoptosis. The one that plays an important role in the carcinogenesis process is the apoptosis process.

Alkaloids show strong biological activity. It is estimated that more than 2000 compounds are classified as alkaloids, some of them from the Apocynaceae family which are generally used as 
anticancer agents (Macabeo et al., 2009). As an anticancer, alkaloid acts on the cytotoxic pathway, anti-proliferation, induces apoptosis, mitotic inhibitors in the G2/M and subG1 phases of the cell cycle, microtubules inhibitor, inhibitor topoisomerase enzyme, anti-metastasis, induces caspase-cascade and anti-angiogenesis.

Cytotoxicity is the level of a substance's toxic activity against a cell. It is one of the most important indicators for biological evaluation in vitro studies. Cancer drugs have different cytotoxic mechanisms: the destruction of cell membranes, prevention of protein synthesis, irreversible binding to receptors, inhibition of polydeoxynucleotide elongation, and enzymatic reactions. The cytotoxic and cell viability tests are required to determine cell death caused by this damage. While the cytotoxic compound can damage normal cells and cancer cells, it is used to inhibit the growth of malignant tumor cells.

Voacanga foetida (Blume) Rolfe, (Apocynaceae) which are found in West Sumatra Indonesia known as "Tampa badak". They are a small tree of 20 meters long, with white sap, stem diameter reaches 40 centimeters. This plant is widely spread in Indonesia, Malaysia, and the Philippines. V. foetida leaves were generally used to treat various skin conditions such as wounds, itching, swelling, and have been used externally for skin disorders (Hadi et al., 2019).

$V$. foetida is high in alkaloids (Susanty et al., 2018). It is a source of the indole alkaloids lombine, voacangine, voacristine, and coronadine (Hadi et al., 2019; Zocoler et al., 2005). It is also known as a source of bis-indole alkaloids or alkaloid dimers vobtusine (Susanty et al., 2020). The bis-indole alkaloid consists of two identical or distinct indole alkaloid monomer units held together by C-C, C-O-C, or C-N bonds. Previous researchers have also shown that the leaves and bark of these plants exhibited potential cytotoxicity activity.

This study is a continuation of our research on other Sumatran plants (Dachriyanus et al., 2000; Hirasawa et al., 2019; Amelia et al., 2019; Susanty et al., 2014). In this work, we reported the structural characterization of vobtusine lactone and the cytotoxic activity of two isolated alkaloids from $V$. foetida against the A549 cell line. The molecular docking study was also performed to predict their cytotoxic mechanism against several pro-survival receptors (Bcl-2, Bcl-xL, Mcl-1), proactivation receptor (Bax), and apoptotic execution receptor (caspase-3).

\section{MATERIAL AND METHODS}

Lung adenocarcinoma (A549) cell line was obtained from Tohoku University, Japan. Chemical reagents used in this work include trypsin-EDTA $0.25 \%$ (Gibco), trypan blue (Invitrogen), penicillin $(10,000$ units $/ \mathrm{mL})$, Streptomycin $(10,000 \mu \mathrm{g} / \mathrm{mL})$, and RPMI 1640 (Wako). The equipment and instrument were used in this work include flask culture (diameter $25 \mathrm{~cm}^{2}$ ), corning $2 \mu \mathrm{m}$, 96 wellplate, $15 \mathrm{~mL}$ and $50 \mathrm{~mL}$ falcon tubes, laminar airflow, $\mathrm{CO}_{2}$ incubator (HERA cell 150, Thermo electron corporation), Biological Safety Cabinet Class II Type A/B3 (Sanyo), Microplate Spectrometer (BIO-RAD), UV Ultra spec 2100 pro, NMR spectrometer (Brucker AV-400), mass spectrometer (ESI-MS Waters ZQ-2000), and CD J820 spectropolarimeter.

\section{Extraction of $V$. foetida bark and isolation of alkaloids}

The $V$. foetida barks were collected from the forest of biological education and research of Andalas University, West Sumatera, in January 2019. The specimen was identified at herbarium Andalas University. The dried bark of $V$. foetida $(5.2 \mathrm{~kg})$ was ground and extracted for five days with methanol (10L). This maceration was repeated twice and the combined extracts were concentrated under reduced pressure. The concentrated extract was diluted with tartaric acid $(3 \%, 500 \mathrm{~mL})$ and then partitioned with dichloromethane $(5 \times 500 \mathrm{~mL})$. The acidic layer was basified with sodium bicarbonate and then extracted with dichloromethane $(5 \times 500 \mathrm{~mL})$. The combined dichloromethane base extract was concentrated under reduced temperature to give a crude alkaloid fraction as a dark brown gum (11.3g).

A portion of crude alkaloid fraction $(10 \mathrm{~g})$ was subjected to column chromatography on amino silica with the increasing amount of ethyl acetate in hexane as eluent. Fractions with contain similar patterns on TLC were combined and as much $100 \mu \mathrm{L}$ of fraction solution $(20 \mathrm{mg} / \mathrm{mL})$ was subjected to HPLC ODS MS-II column $(20 \times 30 \mathrm{~mm})$ and a mixture of $3 \% \mathrm{ACN}$ in $\mathrm{H}_{2} \mathrm{O}(0.1 \%$ formic acid $)$ was used as mobile phase. Resolution factor $(\mathrm{R})=$ 0.16 . Flow rate $=8 \mathrm{~mL} / \mathrm{min}$. The similar HPLC fractions were combined, dried, and recrystallized to give a pure isolated compound. Then, the structure of the pure isolated compound was confirmed by spectroscopic analysis, including UVVis, IR, MS, XRD, 1D, and 2D NMR analysis. In addition, the optical rotation was determined. 
Table I. SMILES data (Pubchem ID and CAS Number) were created using the MOE builder application.

\begin{tabular}{|c|c|c|}
\hline Compunds & Identity & Structure "SMILES" \\
\hline Vocangine & $\begin{array}{l}\text { Pubchem ID } 73255 \\
\text { CAS Number 510-22-5 }\end{array}$ & $\begin{array}{l}\text { CCC1CC2CC3(C1N(C2)CCC4=C3NC5=C4C=C(C=C5)OC)C } \\
(=0) O C\end{array}$ \\
\hline Vobtusine & $\begin{array}{l}\text { Pubchem ID } 301819 \\
\text { CAS Number } 19772-79-3\end{array}$ & $\begin{array}{l}\mathrm{COC} 1=\mathrm{CC}=\mathrm{CC} 2=\mathrm{C} 1 \mathrm{~N} 3 \mathrm{CC} 4(\mathrm{CC} 5 \mathrm{C} 3(\mathrm{C} 26 \mathrm{CCN} 7 \mathrm{C} 6 \mathrm{C} 8(\mathrm{C} 5) \mathrm{CCO} \\
\mathrm{C} 8 \mathrm{CC} 7) 0) \mathrm{CN} 9 \mathrm{CCC} 12 \mathrm{C} 9 \mathrm{C} 3(\mathrm{C} 40 \mathrm{CC} 3) \mathrm{CC}(=\mathrm{C} 1 \mathrm{NC} 1= \\
\mathrm{CC}=\mathrm{CC}=\mathrm{C} 21) \mathrm{C}(=0) \mathrm{OC}\end{array}$ \\
\hline $\begin{array}{l}\text { Vobtusine } \\
\text { lactone }\end{array}$ & CAS Number 19772-81-7 & $\begin{array}{l}\mathrm{COC} 1=\mathrm{CC}=\mathrm{CC} 2=\mathrm{C} 1 \mathrm{~N} 3 \mathrm{CC} 4(\mathrm{CC} 5 \mathrm{C} 3(\mathrm{C} 26 \mathrm{CCN} 7 \mathrm{C} 6 \mathrm{C} 8(\mathrm{C} 5) \mathrm{CC} \\
(=0) 0 \mathrm{C} 8 \mathrm{CC} 7) 0) \mathrm{CN} 9 \mathrm{CCC} 12 \mathrm{C} 9 \mathrm{C} 3(\mathrm{C} 40 \mathrm{CC} 3) \mathrm{CC}(=\mathrm{C} 1 \mathrm{NC} 1=\mathrm{CC}= \\
\mathrm{CC}=\mathrm{C} 21) \mathrm{C}(=0) \mathrm{OC}\end{array}$ \\
\hline Abt-199 & Pubchem ID 49846579 & $\begin{array}{l}\mathrm{CC} 1(\mathrm{CCC}(=\mathrm{C}(\mathrm{C} 1) \mathrm{C} 2=\mathrm{CC}=\mathrm{C}(\mathrm{C}=\mathrm{C} 2) \mathrm{Cl}) \mathrm{CN} 3 \mathrm{CCN}(\mathrm{C} \text { C3)C4=CC }(=) \\
\mathrm{C}(\mathrm{C}=\mathrm{C} 4) \mathrm{C}(=\mathrm{O}) \mathrm{NS}(=\mathrm{O})(=\mathrm{O}) \mathrm{C} 5=\mathrm{CC}(=\mathrm{C}(\mathrm{C}=\mathrm{C} 5) \mathrm{NCC} 6 \mathrm{CCOCC} 6) \\
[\mathrm{N}+](=0)[\mathrm{O}-]) \mathrm{OC} 7=\mathrm{CN}=\mathrm{C} 8 \mathrm{C}(=\mathrm{C} 7) \mathrm{C}=\mathrm{CN} 8) \mathrm{C}\end{array}$ \\
\hline Abt-702 & Pubchem ID 10341154 & $\begin{array}{l}\mathrm{C} 1 \mathrm{COCCN} 1 \mathrm{C} 2=\mathrm{NC}=\mathrm{C}(\mathrm{C}=\mathrm{C} 2) \mathrm{C} 3=\mathrm{NC} 4=\mathrm{NC}=\mathrm{NC}(=\mathrm{C} 4 \mathrm{C}(=\mathrm{C} 3) \mathrm{C} 5= \\
\mathrm{CC}(=\mathrm{CC}=\mathrm{C} 5) \mathrm{Br}) \mathrm{N}\end{array}$ \\
\hline Kaempheritrin & Pubchem ID 5486199 & $\begin{array}{l}\mathrm{CC} 1 \mathrm{C}(\mathrm{C}(\mathrm{C}(\mathrm{C}(\mathrm{O} 1) \mathrm{OC} 2=\mathrm{CC}(=\mathrm{C} 3 \mathrm{C}(=\mathrm{C} 2) \mathrm{OC}(=\mathrm{C}(\mathrm{C} 3=0) \text { OC } 4 \mathrm{C} \\
(\mathrm{C}(\mathrm{C}(\mathrm{C}(\mathrm{O}) \mathrm{C}) \mathrm{C}) 0) 0) \mathrm{C} 5=\mathrm{CC}=\mathrm{C}(\mathrm{C}=\mathrm{C} 5)\end{array}$ \\
\hline
\end{tabular}

\section{Cytotoxic assay}

The Cytotoxic assay was determined using MTT assay by following the previous procedure (Susanty et al., 2020). Approximately 5000 cells/ well of A549 cell line were plated in a 96-well plate $\left(90 \mu \mathrm{L} /\right.$ well) andincubated at $37^{\circ} \mathrm{C}$ in $\mathrm{CO}_{2}$ incubator. The cells were cultured in $5 \% \mathrm{CO}_{2}$ for $24 \mathrm{~h}$. Various concentrations of the samples in DMSO $(10 \mu \mathrm{L})$ were added to the cell culture $(20 \mu \mathrm{g} / \mathrm{mL}$ for screening and four various concentrations of 5, 10, 20 , and $40 \mu \mathrm{g} / \mathrm{mL}$ for $\mathrm{IC}_{50}$ calculation) and were incubated for $48 \mathrm{~h}$. Vinblastine solution was used as a positive control with a concentration of $100 \mathrm{ng}$. As much as $15 \mu \mathrm{L}$ of MTT (3-(4,5-Dimethylthiazol-2yl)-2,5-diphenyltetrazolium bromide, SIGMA) solution $(5 \mathrm{mg} / \mathrm{mL})$ was added and the mixtures were incubated in a $\mathrm{CO}_{2}$ incubator $\left(37^{\circ} \mathrm{C}, 5 \% \mathrm{CO}_{2}\right)$ for two hours. After confirming the formation of formazan, $100 \mu \mathrm{L}$ of Stop Solution $(10 \% \mathrm{SDS}-\mathrm{HCl})$ was added to dissolve formazan. Optical density was measured using an ELISA microtiter plate reader at $550 \mathrm{~nm}$ and $700 \mathrm{~nm}$ (background). The cell viability (\%) was determined by the following formula.

Cell viability $(\%)=\frac{(A-B)}{(C-B)} \times 100 \%$

In this case, $A=$ absorbance of media + cell + sample, $\mathrm{B}=$ absorbance of media, $\mathrm{C}=$ absorbance of media + cell.

\section{Molecular docking study}

All ligands used in this study have been reported as anticancer, even Susanty et al. (2020) recently reported that the anticancer mechanism of vobtusine is to suppress the expression and function of the Bcl-2 protein, in turn triggering an increase in the expression of Bax and caspase-3. Likewise, the Abt-199, Abt-702, and kaempheritrin which were used as controls have also been reported to have their respective functions in suppressing Bcl-2 expression, increasing Bax and caspase-3 expression.

The structures of ligands were built from SMILES data (Pubchem ID and CAS Number) using the MOE builder application (Table I), while receptors were downloaded from www.pdb.org. These receptors include pro-survival protein $\mathrm{Bcl}-2$ (PDB ID 2W3L), Bcl-xL (PDB ID 2YXJ), Mcl-1 (PDB ID 3KZ0); pro-apoptotic protein Bax (PDB ID 1F16); and apoptotic execution protein caspase-3 (PDB ID 1GFW).

The ligands and receptors were prepared and their 3-dimensional structures were optimized by adding hydrogen, removing water molecules, adding partial charges, and minimizing energy. Then, the binding site was selected using the default MOE system and the ligands were docked onto the receptors. The docking complex was stored in pdb format, while the docking data were saved in mdb format and the ligand-receptor interaction was visualized. 


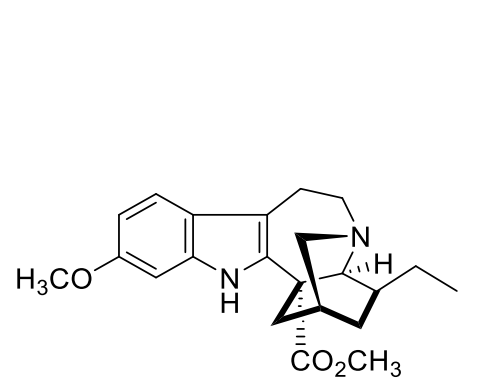

(a)

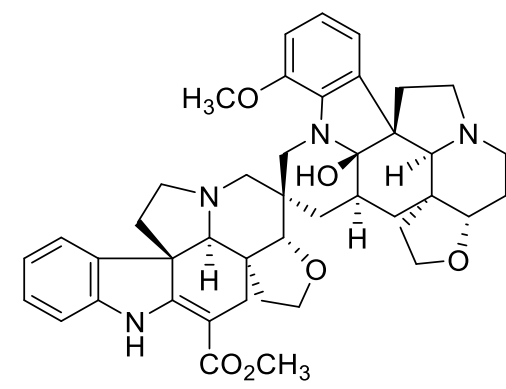

(b)

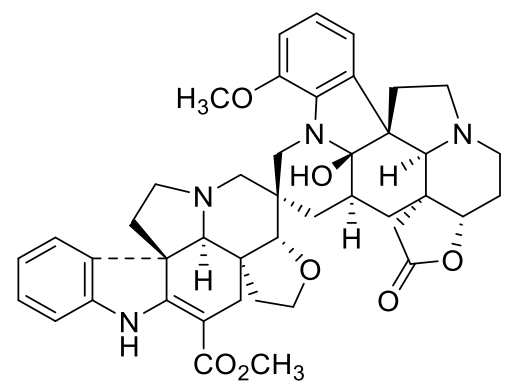

(c)

Figure 1. The structure of isolated compounds, (a) voacangine (Zocoler et al., 2005), (b) vobtusine (Susanty et al., 2020), and (c) vobtusine lactone $\left(\mathrm{C}_{43} \mathrm{H}_{48} \mathrm{~N}_{4} \mathrm{O}_{7}\right)$ from DCM base fraction of $V$. foetida (VFB-DB2\&3).

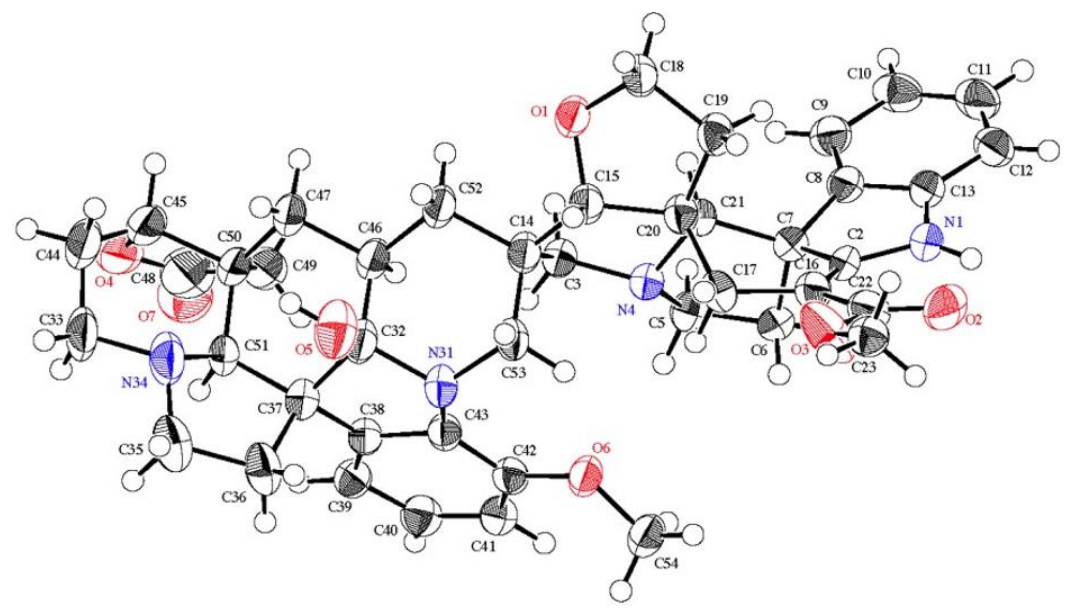

Figure 2. Crystallography structure of vobtusine lactone obtained by XRD analysis [Flack parameter 2776 Friedel pairs were 0.3].

\section{RESULT AND DISCUSSION}

The structure and the crystallography structure of vobtusine lactone in this work were depicted in Figure I and Figure 2. The compound was isolated from the DCM base fraction of $V$. foetida (VFB-DB2\&3).

\section{Characteristic of an isolated compound}

The similar fractions were combined, dried, and recrystallized using a mixture of $n$ hexane/ethyl acetate to give pure vobtusine lactone $(10.9 \mathrm{mg})$. The compound was obtained as a colorless platelet crystal which decomposed at $300^{\circ} \mathrm{C}$ and $[\alpha] 26 \mathrm{D}=-2.41$ (c. $\left.0.1, \mathrm{MeOH}\right)$.

The UV absorption bands of isolated compound (vobtusine lactone) at $\max 239.5 \mathrm{~nm}$ ( $\varepsilon=20042.2), 267.1 \mathrm{~nm}(\varepsilon=14186.2)$, and $321.9 \mathrm{~nm}$ $(\varepsilon=20042.2)$ indicated two indole chromophores. The IR spectrum showed an absorption band at $3370 \mathrm{~cm}^{-1}$. This absorption band indicates the presence of $\mathrm{N}-\mathrm{H}$ and $\mathrm{O}-\mathrm{H}$ bonds. The absorption band at $1600 \mathrm{~cm}^{-1}$ indicates the presence of a $\mathrm{C}=0$ bond and the absorption band at $2905 \mathrm{~cm}^{-1}$ indicates the presence of an aliphatic $\mathrm{C}-\mathrm{H}$ bond. The ESIMS+ spectra showed the molecular ion peak at $\mathrm{m} / \mathrm{z}=731.5$ and it was matched with the molecular formula of vobtusine lactone, $\mathrm{C}_{43} \mathrm{H}_{48} \mathrm{~N}_{4} \mathrm{O}_{7}$ (Kunesch et al., 1976).

The 1D and 2D NMR analyses were also performed to ensure the structure of the isolated compound. The ${ }^{1}$ HNMR spectra indicated the presence of an aromatic methoxy proton at 3.73ppm. Based on the HMBC analysis, the proton correlates with an oxy-aryl carbon (C12') at 145.3ppm. The ${ }^{1} \mathrm{H}$ NMR spectra also indicate the presence of carbomethoxy proton at $3.79 \mathrm{ppm}$. Based on the HMBC analysis, the proton correlates with the carbonyl of ester at $168.7 \mathrm{ppm}$. In addition, the presence of $\mathrm{N}-\mathrm{H}$ proton in indole moiety was indicated by the singlet signal at $8.93 \mathrm{ppm}$. 


\section{Adriani Susanty}

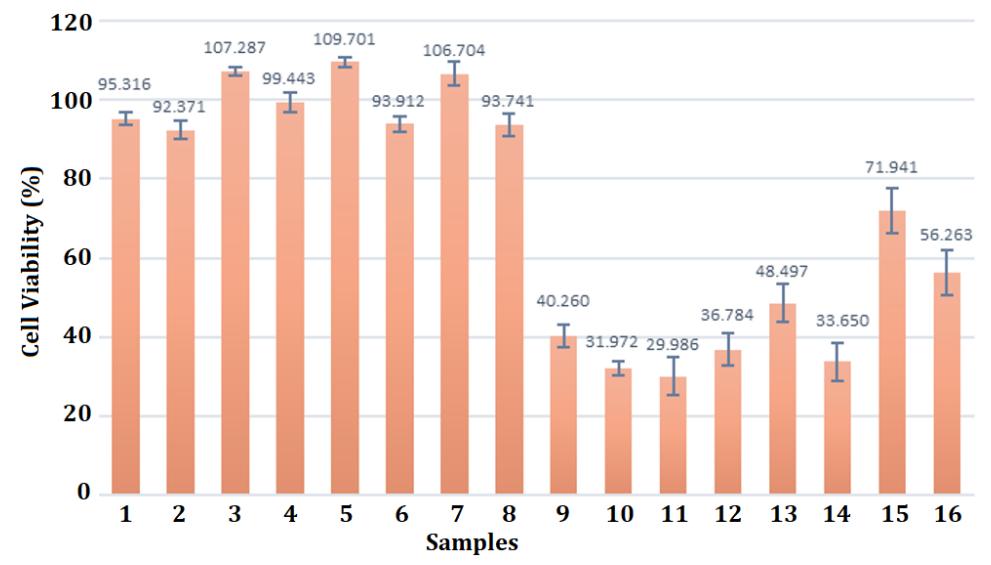

Figure 3. Percentage of cell viability of extracts, fractions, and isolated compounds from $V$. foetida (tested concentration $=20 \mu \mathrm{g} / \mathrm{mL}$ ). Sample 1 (VFL-Hex), 2 (VFL-EtOAc), 3 (VFL-EtOH), 4 (VFL-MeOH), 5 (VFLDA), 6 (VFL-DB), 7 (VFL-BuOH), 8 (VFB-MeOH), 9 (VFB-DA), 10 (VFB-DB), 11 (VFB-BuOH), 12 (Voacangine), 13 (Vobtusine lactone), 14 (VFB-DB 4), 15 (VF-F19/20), and 16 (Vinblastine, 100ng). VFL = Voacanga foetida leaves, VFB $=$ Voacanga foetida bark, Hex $=n$-hexane, EtOAc $=$ ethyl acetate, EtOH $=$ ethanol, $\mathrm{MeOH}=$ methanol, $\mathrm{DA}=\mathrm{DCM}$ acid, $\mathrm{DB}=\mathrm{DCM}$ base, $\mathrm{BuOH}=n$-butanol

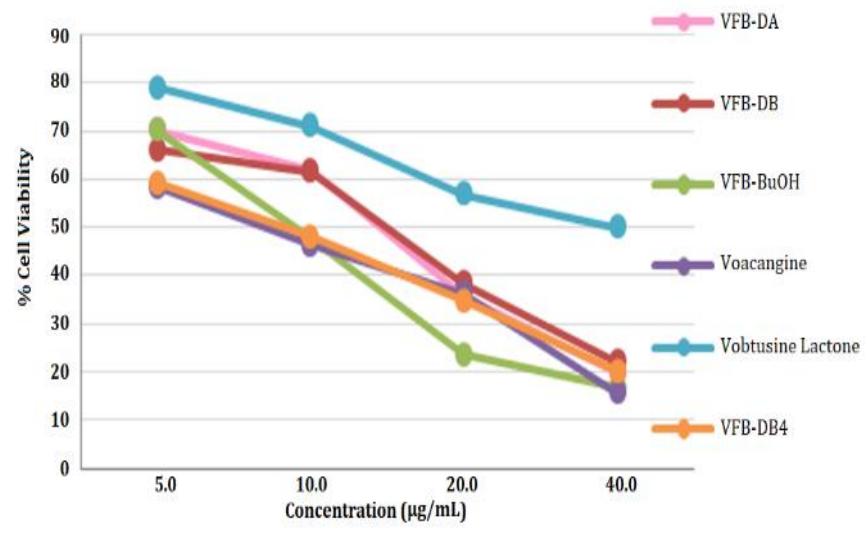

Figure 4. Percentage of cell viability of VFB-DA, VFB-DB, VFB-BuOH, Voacangine, Vobtusine lactone, and VFB-DB4 from $V$. foetida at various concentrations against A549 cell line at 48 hours incubation.

Then, the ${ }^{13} \mathrm{C}$ NMR spectra also indicated the presence of carbonyl of lactone at $175.5 \mathrm{ppm}$. This signal is important to determine whether the isolated compound is vobtusine or vobtusine lactone. Overall, the correlations in HSQC and HMBC spectra showed a suitable correlation with the structure of vobtusine lactone, and have high similarity with previously reported NMR spectra of vobtusine lactone isolated from Tabernaemontana sphaerocarpa Blume is a member of the Apocynaceae family (Zaima et al., 2009).

Vobtusine lactone was crystallized from $\mathrm{MeOH}$ to give colorless platelet crystal. Crystal data: $a=11.3328$ (2) $\AA$, b=12.1330 (2) $\AA$, c=13.9244 (4) $\AA 3, \beta=110.3716$ (4), V= 1794.87(10) $\AA^{3}, Z=2$, $\mathrm{FW}=750.89, \mathrm{D}$ calc $=1.389 \mathrm{~g} / \mathrm{cm}, \mu$ for $\mathrm{Cu} \mathrm{K \alpha}$ radiation is $7.841 \mathrm{~cm}^{-1}, \mathrm{~T}=-180 \pm 1{ }^{\circ} \mathrm{C}$. The structure was solved by direct methods and expanded using Fourier techniques. The nonhydrogen atoms were refined anisotropic, Hydrogen atoms were refined using the riding model. The final cycle of full-matrix least-squares refinement on F2 was based on 3441 observed reflections and converged with unweighted and weighted agreement factors of R1 $=0.0677$ $[\mathrm{I}>2.00 \sigma(\mathrm{I})]$ and $w \mathrm{R} 2=0.1967$. 
Table II. IC ${ }_{50}$ value and cytotoxic classifications of fractions and isolated compounds from $V$. foetida against A549 cell line

\begin{tabular}{lll}
\hline Samples & IC $\mathbf{5 0}_{\mathbf{5 0}}(\boldsymbol{\mu} \mathbf{g} / \mathbf{m L})$ & Cytotoxic classifications \\
\hline VFB-DA & 12.3 & Highly Cytotoxic Activity \\
VFB-DB & 12.4 & Highly Cytotoxic Activity \\
VFB-BuOH & 9.5 & Highly Cytotoxic Activity \\
Voacangine & 8.2 & Highly Cytotoxic Activity \\
Vobtusine Lactone & 37.4 & Moderate Activity \\
VFB-DB4 & 8.5 & Highly Cytotoxic Activity \\
\hline
\end{tabular}

\section{Cytotoxicity Activity}

The results of the cytotoxic assay of extracts, fractions, and isolated compounds were performed in triplicate and the results were depicted in Figure 3. The figure explained that four fractions (VFB-DA, VFB-DB, VFB-BuOH, and VFB-DB4), dan two isolated compounds (voacangine and vobtusine lactone) exhibited a lower percentage of cell viability than vinblastine as a positive control at tested concentration. It means that some mentioned fractions and both isolated compounds have a higher ability to reduce the number of A549 cells.

The results of the cytotoxic assay as depicted in Figure 4 were performed in four variations of concentrations $(5 ; 10 ; 20$ and $40 \mu \mathrm{g} / \mathrm{mL})$. The figure showed that voacangine (highlighted in purple line) exhibited the lowest percentage of cell viability at the lowest and highest tested concentrations, while the vobtusine lactone (highlighted in blue line) exhibited the highest percentage of cell viability at all various tested concentrations. Based on the result of $\mathrm{IC}_{50}$ calculation as shown in Table II, vobtusine lactone has moderate cytotoxic activity with $\mathrm{IC}_{50}$ of 37.4 $\mu \mathrm{g} / \mathrm{mL}$, while voacangine and four fractions exhibited very highly cytotoxic activity against A549 cell line.

The results of this study are in line with the study of Chen et al. (2016). Based on the study, voacangine also exhibited very high cytotoxic activity against HEPG-2, A375, MDA-MB-231, SHSY5Y, and CT26 cancer cells with $\mathrm{IC}_{50}$ values of 10 ; 14; 8; 7.7 and $11 \mu \mathrm{g} / \mathrm{mL}$, respectively. Then, the cytotoxic activity of vobtusine lactone has also been reported by Zaima et al. (2018). Vobtusine lactone exhibited $\mathrm{IC}_{50}$ of $8.0 ; 18.0 ; 7.6 ; 17.6$ and $22.5 \mu \mathrm{M}$ against HL-60, RPMI8226, NCI-H226, HCT116, and MCF7 cancer cells, respectively.

The difference in cytotoxic activity between fractions and isolates is thought as a result of voacangine and vobtusine lactone have anticancer mechanisms, not in the cytotoxic pathway but the apoptotic pathway, this estimate is supported by previous research conducted by Macabeo et al. (2005) which states that the fractions of plants $V$. globasa, (same family with $V$. foetida) exhibited strong cytotoxic activity by apoptotic induction through the mitochondrial pathway. This study is also in line with our study. Seeing this reality, this $V$. foetida plant has the potential to be developed as a natural source of both bioactive fractions and compounds to fight cancers by apoptotic induction.

\section{Molecular docking study}

The interaction model of ligand-receptor is further explained in silico via molecular docking techniques. The results of this study show that all ligands (tested compounds and control) have an affinity for all receptor targets. This is characterized by the release of energy when forming complexes with these receptors, but the strength of the affinity is different. The more negative the docking score obtained shows the stronger affinity with the receptor.

The pro-survival protein receptors showed that all three tested ligands (voacangine, vobtusine, and vobtusine lactone) had stronger affinity than controls (Abt-199). The strongest affinity was shown by vobtusine with a docking score of -10.04 $\mathrm{kcal} / \mathrm{mol},-11.69 \mathrm{kcal} / \mathrm{mol}$, and $-10.77 \mathrm{kcal} / \mathrm{mol}$ against Bcl-2, Bcl-xL, and Mcl-1 receptors, respectively (Table III).

In contrast to the pro-apoptotic receptor "Bax", all three tested ligands have weaker affinity than controls. The weakest affinity was shown by vobtusine with a docking score of $-6.86 \mathrm{kcal} / \mathrm{mol}$, then vobtusine lactone with $-6.99 \mathrm{kcal} / \mathrm{mol}$, and voacangine with $-8.99 \mathrm{kcal} / \mathrm{mol}$. Abt-702 as the control ligand shows the strongest affinity with a docking score of $-9.95 \mathrm{kcal} / \mathrm{mol}$ (Table IV). 
Table III. Docking score of ligands with pro-survival receptors

\begin{tabular}{|c|c|c|c|c|c|}
\hline \multirow[b]{2}{*}{ Receptors } & \multicolumn{4}{|c|}{$\Delta G(\mathrm{kcal} / \mathrm{mol})$} & \multirow{2}{*}{ Binding site } \\
\hline & Voa. & Vob. & Vob. Lac. & Cont. & \\
\hline Bcl-2 & -9.93 & -10.07 & -8.31 & -9.03 & $\begin{array}{l}\text { Arg 86, Phe 97, Ala 90, Val 93, Glu 94, Trp 135, Glu } \\
\text { 138, Tyr 139, Arg 142, His } 143\end{array}$ \\
\hline Bcl-xL & -9.77 & -11.69 & -10.29 & -9.76 & $\begin{array}{l}\text { (Thr 115, Pro 116, Gly } 117 \text {, Thr 118, Ala 119, Tyr } 120 \text {, } \\
\text { Leu 162, Trp 169)1; (Tr 120, Phe 123, Glu 124, Val } \\
\text { 127, Asn 128, Trp 169, Thr 172, Tyr 173, Asp 176, } \\
\text { His 177)2 }\end{array}$ \\
\hline Mcl-1 & -10.70 & -10.77 & -10.02 & -9.53 & $\begin{array}{l}\text { (Glu 16, Ans 17, Tyr 20, Tyr 21)1: (Val 216, Gly 219, } \\
\text { Val 220, Asn 223, His 224)2 }\end{array}$ \\
\hline
\end{tabular}

Table IV. Docking score of ligands with pro-apoptotic receptor

\begin{tabular}{|c|c|c|c|c|c|}
\hline \multirow{2}{*}{ Receptor } & \multicolumn{4}{|c|}{$\Delta \mathrm{G}(\mathrm{kcal} / \mathrm{mol})$} & \multirow{2}{*}{ Binding site } \\
\hline & Voa. & Vob. & Vob. Lac & Cont. & \\
\hline Bax & -8.99 & -6.87 & -6.99 & -9.95 & $\begin{array}{l}\text { Tyr 164, Phe 165, Gly 166, Thr } 167 \text {, Thr } 169 \text {, Trp } 170 \text {, } \\
\text { Thr } 172 \text {, Val } 173\end{array}$ \\
\hline
\end{tabular}

Table V. Docking score of ligands with apoptotic execution receptor

\begin{tabular}{|c|c|c|c|c|c|}
\hline \multirow{2}{*}{ Receptor } & \multicolumn{4}{|c|}{$\Delta \mathrm{G}(\mathrm{kcal} / \mathrm{mol})$} & \multirow[b]{2}{*}{ Site Binding } \\
\hline & Voa. & Vob. & Vob. Lac & Cont. & \\
\hline Caspase-3 & -12.05 & -12.21 & -12.02 & -14.25 & $\begin{array}{l}\text { (Thr 62, Ser 65, Gly 66, His 121, Cys 163)1; (Tyr 204, } \\
\text { Ser 205, Trp 206, Arg 207, Asn 208, Ser 209, Phe } \\
\text { 256)2 }\end{array}$ \\
\hline
\end{tabular}

Likewise, with the caspase-3 protein receptor, all three tested ligands showed weaker affinity than the docked ligand (kaempheritrin). Each releases energy of $-12.05 \mathrm{kcal} / \mathrm{mol}$ (voacangine), $-12.21 \mathrm{kcal} / \mathrm{mol}$ (vobtusine), -12.02 $\mathrm{kcal} / \mathrm{mol}$ (vobtusine lactone). Kaempheritrin as a control ligand releases greater energy (-14.25 $\mathrm{kcal} / \mathrm{mol}$ ) (Table V).

Hydrogen bonding sufficiently affects the level of ligand affinity when interacting with the pro-survival protein receptor (Bcl-2) (Figure 5). The interaction of the vobtusine with the Bcl-2 receptor showed that the presence of 2 hydrogen bonds on the Tyr-139 and Arg-142 residues obtained an affinity of $-10.07 \mathrm{kcal} / \mathrm{mol}$. The presence of 1 hydrogen bond between the vobtusine lactone and the $\mathrm{Bcl}-2$ receptor on the Arg-142 residue obtained an affinity of -8.31 $\mathrm{kcal} / \mathrm{mol}$. The presence of 1 hydrogen bond of the Abt-199 control ligand with the Bcl-2 receptor on the Arg-142 residue obtained an affinity of -9.03 $\mathrm{kcal} / \mathrm{mol}$ (Table III). Thus, the more hydrogen bonds formed, the greater the affinity.
However, the amount of affinity is not only determined by the presence of hydrogen bonds. The voacangine does not show the formation of a hydrogen bond with the Bcl-2 receptor, but the strength of the affinity is quite large, reaching $-9.93 \mathrm{kcal} / \mathrm{mol}$. The voacangine has a simpler structure, this is what makes it easier for voacangine to enter the binding site of the Bcl-2 receptor. This statement is supported by (Saffari-Chaleshtori et al., 2019) who reported the inhibitory activity of thymoquinone against Bcl2. Even though when interacting with the Bcl-2 receptor, this compound does not form hydrogen bonds at all, this compound has a simple spatial structure that allows easy entry to the Bcl-2 receptor binding site.

Likewise, the Bcl-xL receptor shows that the number of hydrogen bonds is not a dominant factor in increasing of the ligand affinity for the Bcl-xL receptor (Figure 6). The voacangine ligand formed one hydrogen bond when interacting with Bcl-xL at residue Arg-165 with an affinity of -9.77 $\mathrm{kcal} / \mathrm{mol}$. 


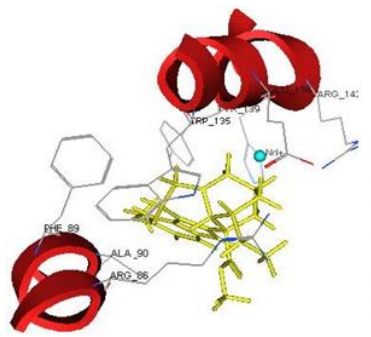

Voacangine

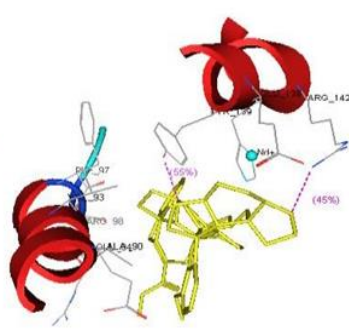

Vobtusine

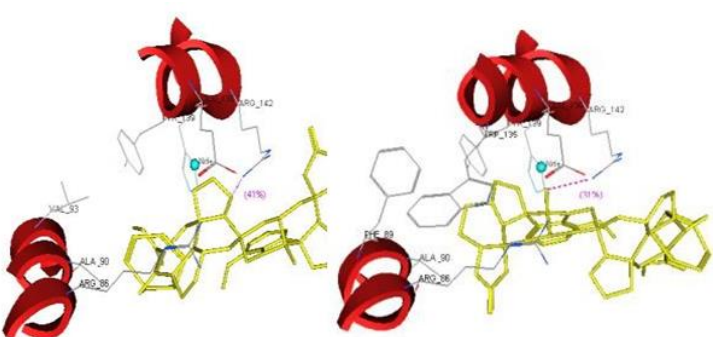

Vobtusine lactone

Abt-199

Figure 5. Models of ligand interactions with Bcl-2 receptor

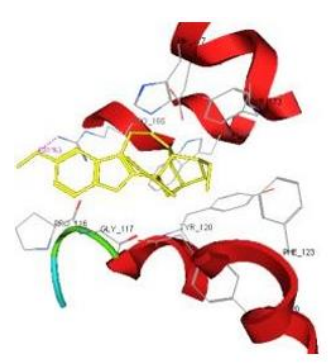

Voacangine

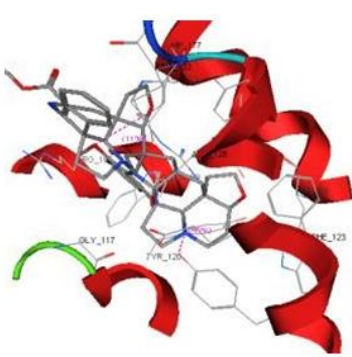

Vobtusine

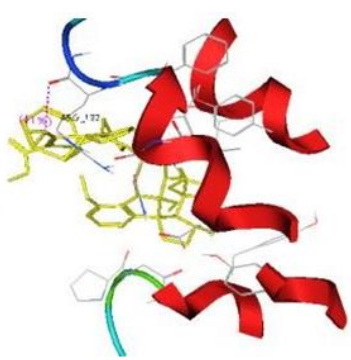

Vobtusine lactone

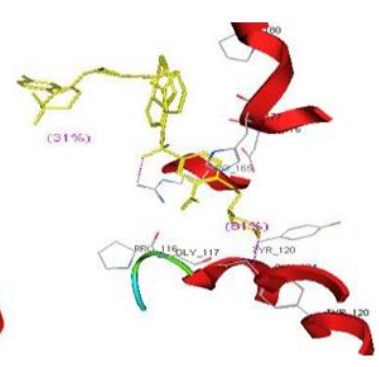

Abt-199

Figure 6. Models of ligand interactions with Bcl-xL receptor

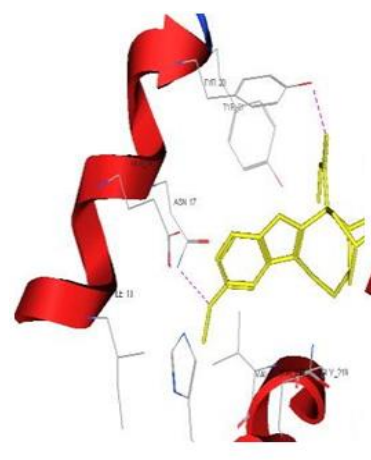

Voacangine

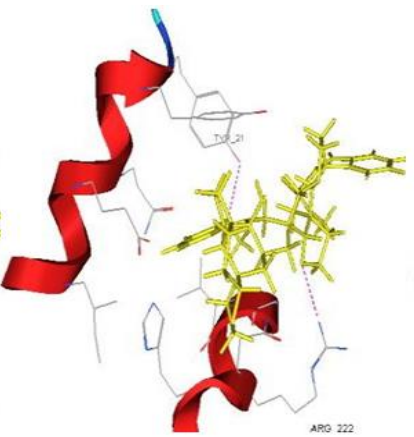

Vobtusine

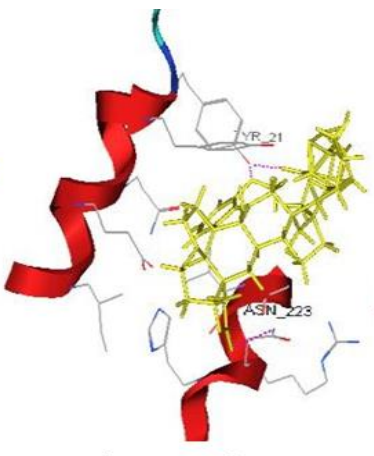

Vobtusine lactone

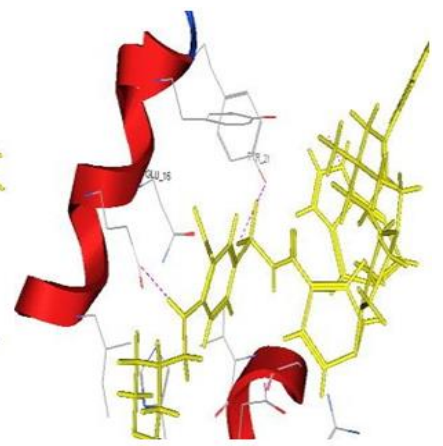

Abt-199

Figure 7. Models of ligand interactions with Mcl-1 receptor

2D

Structure

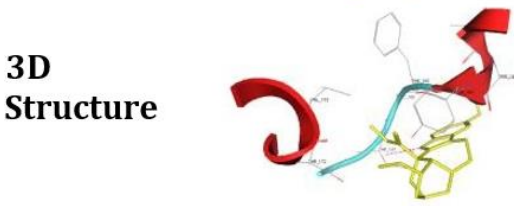

Vocangine

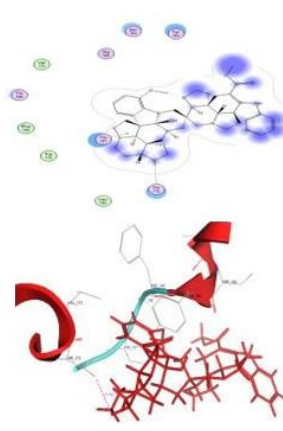

Vobtusine

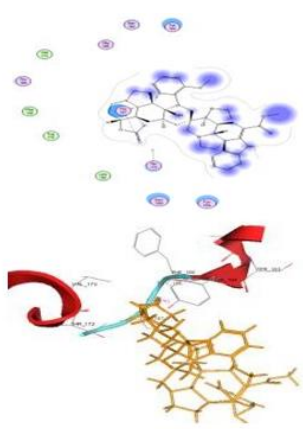

Vobtusine Lactone
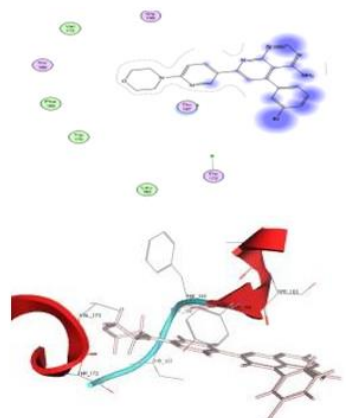

Abt-702 (Control)

Figure 8. Models of ligand interactions with Bax receptor 


\section{Adriani Susanty}

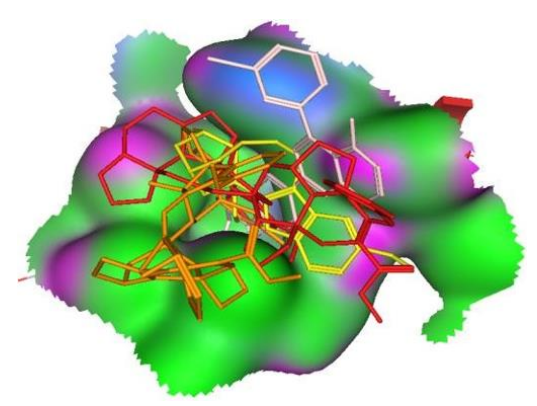

Figure 9. Interaction model of ligands [voacangine (yellow), vobtusine (red), vobtusine lactone (orange), and control (white)] vs Bax receptor with a narrow gap of non-polar "hydrophobic groove" (Blue = semipolar residue, Purple = polar residue, and Green $=$ non-polar residue .

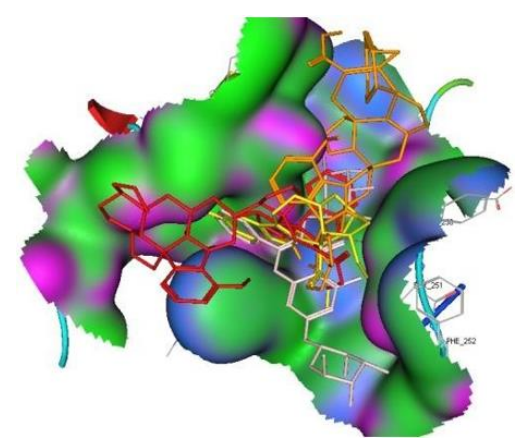

Figure 10. Interaction model of ligands [voacangine (yellow), vobtusine (red), vobtusine lactone (orange), and control (white)] with caspase-3 receptor. The binding site area having polar and semi-polar residues (Blue = semi-polar residue, Purple = polar residue, and Green $=$ non-polar residue $)$.

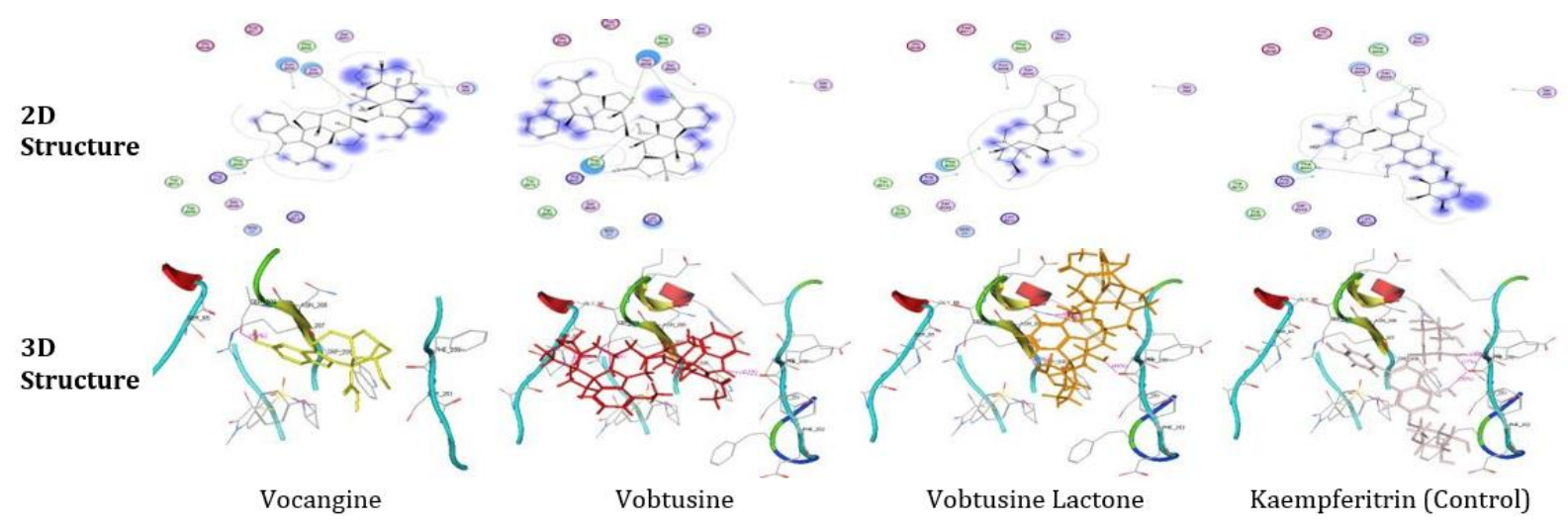

Figure 11. Models of ligand interactions with caspase-3 receptor

The vobtusine lactone formed one hydrogen bond when interacting with Bcl-xL at residue Arg132 with an affinity of $-10.29 \mathrm{kcal} / \mathrm{mol}$. Meanwhile, the vobtusine formed two hydrogen bonds when interacting with Bcl-xL at Tyr-120 and His-177 residues with the strongest affinity of -11.69 $\mathrm{kcal} / \mathrm{mol}$. Likewise, the Abt-199 as control ligand formed two hydrogen bonds when interacting with Bcl-xL at Tyr-120 and Arg-165 residues but with the weakest affinity of $-9.76 \mathrm{kcal} / \mathrm{mol}$ (Table III).

The Mcl-1 receptor showed a ligand interaction pattern that was not different from the Bcl-2 or Bcl-xL receptors (Figure 7). Although vobtusine has two hydrogen bonds (Asn-12 and 
Tyr-21) which gives the strongest affinity of -10.77 $\mathrm{kcal} / \mathrm{mol}$, the vobtusine lactone has three hydrogen bonds (2 Tyr-21 and Arg-222) but gives a lower affinity with the value of $-10.02 \mathrm{kcal} / \mathrm{mol}$. Likewise, voacangine formed three hydrogen bonds (2 Tyr21 and As-223) with affinity $-10.70 \mathrm{kcal} / \mathrm{mol}$, and the Abt-199 as control ligand also with three hydrogen bonds (Glu-16 and 2 Tyr-21) but the affinity is even the weakest of $-9.53 \mathrm{kcal} / \mathrm{mol}$ (Table III).

The same interaction pattern is shown by the pro-apoptotic protein receptor "Bax" (Figure 8). The strongest affinity value was indicated by Abt-702 as a control ligand $(-9.95 \mathrm{kcal} / \mathrm{mol})$ with a simpler structure, the same was seen in the voacangine has one hydrogen bond with the second strongest affinity value of $-8.99 \mathrm{kcal} / \mathrm{mol}$. Furthermore, the vobtusine and vobtusine lactone have lower affinity values of -6.87 and -6.99 $\mathrm{kcal} / \mathrm{mol}$, respectively (Table IV).

Interestingly, the Bax receptors have a "hydrophobic groove" gap for the ligand to enter the binding site (Figure 9). Interaction model of ligands [voacangine (yellow), vobtusine (red), vobtusine lactone (orange), and control (white)] vs Bax receptor with a narrow gap of non-polar "hydrophobic groove" (blue = semi-polar residue, purple $=$ polar residue, and green $=$ non-polar residue).

This gap greatly determines the affinity of the ligands that interact with it (Liu et al., 2016). The smaller molecular weight ligands can infiltrate the narrow gap of the "hydrophobic groove" to interact with these Bax receptors. The structure of the Abt-702 control ligand with two benzoyl ring branches can reach a wider area of the binding site so that it has a stronger affinity than the vobtusine and vobtusine lactone with larger structures.

The caspase- 3 protein receptor shows that the binding site is dominated by polar (purple) and semi-polar (blue) residues (Figure 10). The interaction model of ligands [voacangine (yellow), vobtusine (red), vobtusine lactone (orange), and control (white)] with the caspase-3 receptor. The binding site area having polar and semi-polar residues $($ Blue $=$ semi - polar residue, Purple $=$ polar residue, and Green = non-polar residue).

This binding site pattern allows the control ligand of kaempheritrin, a flavonoid derivative that has three benzoyl side chains to reach three sides of the caspase- 3 binding site with bonds to the semi-polar residue. Besides, there are three hydrogen bonds formed between the kaempheritrin ligand and the Phe-250 residue. The ability of the kaempheritrin ligand to reach the three sides of the caspase- 3 binding site also contributes to the strength of the affinity to be the strongest, which is $-14.24 \mathrm{kcal} / \mathrm{mol}$.

The vobtusine and vobtusine lactone with four hydrogen bonds also showed strong affinities with $-12.21 \mathrm{kcal} / \mathrm{mol}$ and $-12.02 \mathrm{kcal} / \mathrm{mol}$, respectively, but they were unable to reach all sides of the caspase- 3 binding site. Hydrogen bonding in the residue (Table V) was reported as a typical description of the potential of the ligand as a caspase-3 protein activator (Jhansi Lakshmi et al., 2009). The interaction models were further illustrated in Figure 11.

\section{CONCLUSION}

Indole and bis-indole alkaloids were isolated from $V$. foetida. Two compounds (voacangine and vobtusine) have been reported by previous workers and one compound (vobtusine lactone) was first isolated from this plant species. The result of the molecular docking study and in vitro cytotoxic evaluation explains that all fractions (VFB-DB4, VFB-BuOH, VFB-DA, VFB-DB) and isolated compounds (voacangine, vobtusine, and vobtusine lactone) exhibited potential cytotoxic activity. The result suggests that this plant has the potential to be developed as a natural source of both bioactive fractions and compounds to fight lung cancer by apoptotic induction via suppressing Bcl-xL and Mcl- 1 and activating Bax and caspase-3. However, toxicity evaluation is required to ensure their safety as natural anticancer agents.

\section{ACKNOWLEDGMENT}

This work was partially supported by GrandAID for Scientific Research (C) Grant Number 19K07152, The Science Research Promotion Fund from The Promotion and Mutual Aid Corporation for Private Schools of Japan, Professor Grant Andalas University No. T/38/UN.16.17/ PP. GKKPR1GB/LPPM/2019 and Sekolah Tinggi Ilmu Farmasi Riau.

\section{REFERENCES}

Amelia, P., Nugroho, A. E., Hirasawa, Y., Kaneda, T, Tougan, T., Horii, T., and Morita, H. (2019). "Two new sarpagine-type indole alkaloids and antimalarial activity of 16demethoxycarbonylvoacamine from Tabernaemontana macrocarpa Jack," Journal of Natural Medicines. 73(4). 820825. 
http://dx.doi.org/10.1007/s11418-02101510-4

Chen, H. M., Yang, Y. T., Li, H. X., Cao, Z. X., Dan, X. M., Mei, L., Guo, D., Le-Song, C. X., Dai, Y., Hu, J., \& Deng, Y. (2016). Cytotoxic monoterpenoid indole alkaloids isolated from the barks of Voacanga africana Staph. Natural Product Research30(10). 1144-1149. https:://doi.org/10.1080/14786419.2015.1 $\underline{046132}$

Dachriyanus, Arbain, D., Putra, D. P., Sargent, M. V., Susila, R., \& Wahyuni, F. S. (2000). Indole alkaloids from two species of Ophiorrhiza. Australian Journal of Chemistry. 53(3). 221224. https://doi.org/10.1071/ch99112

Dachriyanus, Sargent, M. V., \& Wahyuni, F. S. (2000). (+)-Isochimonanthine, a pyrrolidinoindole alkaloid from Argostemma yappii king. Australian Journal of Chemistry, 53(2). 159-160. https://doi.org/10.1071/ch99114

Hadi, S., Desy R. B., Septiyana, M., Priyambodo, S., \& Sudarma, I. M. (2019). Antibacterial Assay and Alkaloid Lombine Distribution Study of Voacanga foetida (BI.) Rolfe from Lombok Island. Oriental Journal of Chemistry. 35(1) 275-282.

https://doi.org/10.13005/ojc/350133

Hirasawa, Y., Dai, X., Deguchi, J., Hatano, S., Sasaki, T., Ohtsuka, R., Nugroho, A. E., Kaneda, T. , \& Morita, H. (2019). "New vasorelaxant indole alkaloids, taberniacins $\mathrm{A}$ and $\mathrm{B}$, from Tabernaemontana divaricata," Journal of Natural Medicine., 73(3). 627-632.

https://doi.org/10.1007/s11418-01901293-9

Jhansi-Lakshmi, P., Suneel-Kumar, B. V. S., Nayana, R. S., Srinivas, M., Bolligarla, R., Das, S. K., Uday B. M., Kondapi, A. K., \& Ravikumar, M. (2009). Design, synthesis, and discovery of novel non-peptide inhibitor of caspase-3 using ligand-based and structure-based virtual screening approach. Bioorganic and Medicinal Chemistry. 17(16). 6040-604. https://doi.org/10.1016/j.bmc.2009.06.06 $\underline{9}$.

Kunesch, N., Rolland, Y., Poisson, J., Hagaman, E. W., Schell, F. M., Wenkert, E. (1976). Voacanga alkaloids. Journal of Organic Chemistry. 41(20). 3270-3275.

Kyzas, P. A., Stefanou, D., \& Agnantis, N. J. (2004). Immunohistochemical expression of vascular endothelial growth factor correlates with positive surgical margins and recurrence in $\mathrm{T} 1$ and $\mathrm{T} 2$ squamous cell carcinoma (SCC) of the lower lip. Oral Oncology. 40(9). 941-7.

https://doi.org/10.1016/j.oraloncology.20 04.04.018

Liu, Z., Ding, Y., Ye, N., Wild, C., Chen, H., \& Zhou, J. (2016). Direct Activation of Bax Protein for Cancer Therapy. Medicinal Research Reviews. 36(2). 313-341. https://doi.org/10.1002/med.21379.

Macabeo, A. P., Alejandro, G. J., Hallare, A., Vidar, W., \& Villaflores, O. (2009). Phytochemical survey and pharmacological activities of the indole alkaloids in the genus Voacanga Thouars (Apocynaceae) - An update. Pharmacognosy Reviews, 3(5). 143-153. https://www.phcogrev.com/sites/default/f iles/PhcogRev-3-5-143.pdf

Macabeo, A. P. G., Krohn, K., Gehle, D., Read, R. W., Brophy, J., Cordell, G. A., Franzblau, S. G., \& Aguinaldo, A. M. (2005). Indole alkaloids from the leaves of Philippine Alstonia scholaris. Phytochemistry, 66(10). 11581162.

https://doi.org/10.1016/i.phytochem.2005 .02 .018 .

Saffari-Chaleshtori, J., Heidari-Sureshjani, E., MoradiF., \& Heidarian, E. (2019). The effects of thymoquinone on viability, and antiapoptotic factors (BCL-XL, BCL-2, MCL-1) in Prostate Cancer (PC3) cells: An in vitro and computer-simulated environment study. Advanced Pharmaceutical Bulletin. 9(3). 490-496.

https://doi.org/10.15171/apb.2019.058

Susanty, A., Fernando, A., \& Adelin, I. (2014). Efek Analgetik Ekstrak Etanol Daun Tumbuhan Voacanga foetida (Bl.) K. Schum) pada Tikus Putih Jantan. Jurnal Sains Farmasi \& Klinis. 1(1). 1-9.

https://doi.org/10.25077/isfk.1.1.1-9.2014

Susanty, A., Dachriyanus, D., Yanwirasti, Y., Wahyuni, F. S., Fadhli, H., \& Aswan, P.A. (2018). Aktivitas Sitotoksik Ekstrak Etil Asetat Daun Tampa Badak (Voacanga foetida (Bl.) K.Schum) pada Kanker Kolon HTB-38. JSFK (Jurnal Sains Farmasi \& Klinis), 5(2). 142-146.

https://doi.org/10.25077/ISFK.5.2.142146.2018

Susanty, A., Dachriyanus, Yanwirasti, Wahyuni, F. S., Amelia, P., Miyama, S., Hirasawa, Y., Kaneda, T., \& Morita, H. (2020). Vobtusine from Voacanga foetida (Blume) Rolfe 
Induces Apoptosis via Activation of Caspase Pathway in Human HL-60 Leukemia Cell. International Journal on Advanced Science Engineering Information Technology, 10(6). 2536-2541.

http://dx.doi.org/10.18517/ijaseit.10.6.123 $\underline{53}$

Susanty, A., Dachriyanus, Yanwirasti, Wahyuni, F. S., Sekar, A. P., Alimin, N., Magdazaleni, Sofia. S. E., Dewi, C. K. (2020). The Antiproliferation Effect of an Isolated Butanol Fraction of Tampa Badak (Voacanga foetida (Bl.) K.Schum) Leaves on Leukemia, Lung, and Cervical Cancer. Pharmaceutical Science and Research, 7(3). 171-177. https://doi.org/10.7454/psr.v7i3.1196

Zaima, K., Hirata, T., Hosoya, T., Hirasawa, Y., Koyama, K., Rahman, A., Kusumawati, I., Zaini, N. C., Shiro, M., \& Morita, H. (2009).
Biscarpamontamines $\mathrm{A}$ and $\mathrm{B}$, an aspidosperma-iboga bisindole alkaloid and an aspidosperma-aspidosperma bisindole alkaloid, from Tabernaemontana sphaerocarpa. Journal of Natural Products. 72(9). 1686-1690.

https://doi.org/10.1021/np900365r

Zocoler, M.A., de Oliveira, A.J.B., Sarragioto, M.H., Grzesiuk, V.L., Vidotti, G.J. (2005). Qualitative Determination of Indole Alkaloids of Tabernaemontana fuchsiaefolia (Apocynaceae). Journal of Brazilian Chemical Sociaty. 16(6B). 1372-1377. https://doi.org/10.1590/S0103$\underline{50532005000800011}$ 